\title{
Engineered Nanomaterial Impact in the Liver following Exposure via an Intravenous Route-The Role of Polymorphonuclear Leukocytes and Gene Expression in the Organ
}

\author{
Ali Kermanizadeh ${ }^{1 *}$, David M Brown ${ }^{1}$, Gary R Hutchison ${ }^{2}$ and Vicki Stone ${ }^{1}$
}

${ }^{1}$ Heriot-Watt University, School of Life Sciences, Nanosafety Research Group, Edinburgh, EH14 4AS, UK

${ }^{2}$ Edinburgh Napier University, School of Life, Sport and Social Sciences, Sighthill Campus, Sighthill Court, Edinburgh, EH11 4BN, UK

\begin{abstract}
Background and methods: Following exposure via a number of routes (inhalation, ingestion or injection), some Nanomaterials (NMs) translocate to secondary tissues, prominently the liver. This study investigated the effects of an array of NMs, varying in their physicochemical characteristics, consisting of two types of Zinc Oxide (ZnO), two Multiwalled Carbon Nanotubes (MWCNT), one silver $(\mathrm{Ag})$ and one titanium dioxide $\left(\mathrm{TiO}_{2}\right)$ on the liver, following Intravenous (IV) exposure of C57/BL6 mice. The animals were exposed to either a single dose of NM $(128 \mu \mathrm{g} / \mathrm{ml}-100 \mu \mathrm{l})$ or three doses of $(64 \mu \mathrm{g} / \mathrm{ml}-100 \mu \mathrm{l})$, every $24 \mathrm{hr}$. Animals were dissected 6, 24, 48 and $72 \mathrm{hr}$ after the single IV injection, or 72 $\mathrm{hr}$ after the triple injection regime.
\end{abstract}

Results and conclusions: A Myeloperoxidase (MPO) assay was utilised to quantify neutrophil influx into the tissue. However, as MPO is also found in other granulocytes in smaller quantities, the neutrophils in the liver tissue were also labelled, using a specific neutrophil cell surface marker (Ly-6B.2). A wide array of $\mathrm{NMs}$ (including $\mathrm{ZnO}, \mathrm{Ag}, \mathrm{TiO}_{2}$ and MWCNT) induced a neutrophil influx into the liver, as early as $6 \mathrm{hr}$ post IV exposure. However, the neutrophils were only involved in the initial phases of the immune response against the NMs, as the leukocyte numbers had returned to control levels after $48 \mathrm{hr}$. Finally, analysis of mRNA expression in mice livers showed alterations in levels of C3, IL6, IL10, CXCL2 and ICAM-1.

Keywords: Liver; Nanomaterials; Neutrophils; Tissue migration; Gene expression

\section{Introduction}

Engineered Nanomaterials (NMs) (with at least one dimension between 1-100 $\mathrm{nm}$ ) are being developed and exploited because of their unusual and interesting properties exhibited at the nano-scale, compared to larger materials $[1,2]$. These properties have led to their incorporation into over 1300 consumer products [3]. Their widespread utilisation in everyday products suggests that exposure to humans and the environment is ever increasing, and since air pollution particles of similar sizes are known to induce morbidity and mortality [4], concerns about the environmental and human health impacts of NMs have been raised [1].

The lungs and the gastrointestinal tract are in constant contact with the external environment-hence it is not surprising to find these systems being primary exposure sites for NMs $[5,6]$. Research indicates that NMs administered via ingestion, inhalation or intravenous injection rapidly reach secondary tissues, especially the liver [7-9]. As a secondary exposure site, the liver has huge importance, as it has been shown to accumulate NMs at high volumes $(>90 \%)$, compared to other organs $[9,10]$, and alongside the kidneys, may be responsible for the clearance of NMs from the blood [7-9]. The prominent advances in the field of nanomedicine have resulted in an increase in direct entry of NMs into the circulatory system. The presence of nanomaterials in the blood allows distribution to a wide range of target organs, including the liver.

The liver is the metabolic centre of the body [9]. It has a crucial role in metabolic homeostasis, as it is responsible for the storage, synthesis, metabolism and re-distribution of carbohydrates, fats and vitamins. It also produces large numbers of serum proteins and an array of enzymes, cytokines, and various important serum proteins such as complement components and acute phase proteins, crucial in the mammalian innate immune system [11].
Neutrophils also referred to as Polymorphonuclear leukocytes (PMNs) are the most abundant of all white blood cells, comprising of up to $70 \%$ of all leukocytes [12]. Neutrophils are the front line effectors of the innate immune system: after differentiation, these cells circulate in the bloodstream, before migrating into tissues [13]. These cells are solely responsible for surveillance and constituting the first line of defence against foreign antigens [14]. Hence, it is not surprising that in the event of an inflammatory response, there is usually an increase in PMN numbers, mobility, tissue influx and phagocytic ability [12]. Neutrophils are the most active phagocytic cells in the host's immune system arsenal. They are capable of ingestion of antigens into specialised phagosomes, and producing a wide array of cytotoxic agents to eliminate the foreign particle [15]. The role of PMNs in disposal of NMs is not yet fully understood, however, it has been shown that nanomaterial exposure in the lungs results in a large increase in PMN numbers in the tissue [4].

Here, we investigated the leukocyte influx into the liver, following IV exposure of mice to a panel of NMs including $\mathrm{Ag}, \mathrm{ZnO}, \mathrm{TiO}_{2}$ and MWCNT. These NMs, as part of the FP7 ENPRA (Risk assessment of

${ }^{*}$ Corresponding author: Ali Kermanizadeh, Heriot-Watt University, School of Life Sciences, Nanosafety Research Group, Edinburgh, EH14 4AS, UK, Tel: 0131 4514561; E-mail: A.Kermanizadeh@hw.ac.uk

Received November 07, 2012; Accepted December 13, 2012; Published December 17, 2012

Citation: Kermanizadeh A, Brown DM, Hutchison GR, Stone V (2013) Engineered Nanomaterial Impact in the Liver following Exposure via an Intravenous RouteThe Role of Polymorphonuclear Leukocytes and Gene Expression in the Organ. $J$ Nanomed Nanotechol 4: 157. doi:10.4172/2157-7439.1000157

Copyright: (c) 2013 Kermanizadeh A, et al. This is an open-access article distributed under the terms of the Creative Commons Attribution License, which permits unrestricted use, distribution, and reproduction in any medium, provided the original author and source are credited. 
Citation: Kermanizadeh A, Brown DM, Hutchison GR, Stone V (2013) Engineered Nanomaterial Impact in the Liver following Exposure via an Intravenous Route-The Role of Polymorphonuclear Leukocytes and Gene Expression in the Organ. J Nanomed Nanotechol 4: 157. doi:10.4172/2157-7439.1000157

Page 2 of 7

engineered nanoparticles) consortium, were chosen as they represent NMs in a variety of products, and therefore, very real prospect of the materials reaching the blood stream, hence translocating to the liver. In order to confirm whether these nanomaterials could induce a neutrophilic response in the liver, and to identify whether this response was short-lived or more prolonged, as this could potentially be associated with disease initiation. Furthermore, we investigated the changes in the expression of complement factor C (C3), interleukin 6 (IL6), chemokine C-X-C motif Ligand 2 (CXCL2), IL10, Tumour Necrosis Factor- $\alpha$ (TNF- $\alpha$ ), Fas ligand, albumin and Intracellular Adhesion Molecule 1 (ICAM-1) in the liver, following nanomaterial exposure, to gain a better understanding how the organ responds, following a NM challenge.

\section{Materials and Methods}

Nanomaterials were purchased as stated: NM 110 (ZnO-BASF Z-Cote; zinkite, uncoated, $100 \mathrm{~nm}$ ), NM 111 (ZnO-BASF Z-Cote; zinkite coated with triethoxycaprylylsilane, $130 \mathrm{~nm}$ ), NM 300 (AgRAS GmbH; capped with polyoxylaurat Tween $20-<20 \mathrm{~nm}$ ), NM 400 (entangled MWCNT-Nanocyl; diameter $30 \mathrm{~nm}$ ), NM 402 (entangled MWCNT-Arkema Graphistrength C100; diameter $30 \mathrm{~nm}$ ). The above mentioned nanomaterials were sub-sampled under Good Laboratory Practice conditions and preserved under argon in the dark, until use. The $\mathrm{TiO}_{2}$ NRCWE samples were procured by the National Research Centre for the Working Environment. Sub-sampling was completed into $20 \mathrm{ml}$ Scint-Burk glass pp-lock with Alu-Foil (WHEA986581; Wheaton Industries Inc.), after pooling. NRCWE 001, $\mathrm{TiO}_{2}$ rutile 10 $\mathrm{nm}$ was purchased from NanoAmor (Houston, USA), and also used for production of NRCWE $002\left(\mathrm{TiO}_{2}\right.$ rutile $10 \mathrm{~nm}$ with positive charge) [16]. Investigated nanomaterials were characterised by a combination of analytical techniques, in order to infer primary physical and chemical properties useful to understand their toxicological behaviour. A list of the measured physical and chemical properties of the selected NMs was previously described (Supplementary table 1) [16]. Furthermore, the hydrodynamic size distributions of the NMs dispersed in water with $2 \%$ mouse serum was investigated at $1-128 \mu \mathrm{g} / \mathrm{ml}$ concentration range by Dynamic Light Scattering (DLS), using a Malvern Metasizer nano series-Nano ZS (USA) (Table 1).

Female C57/BL6 mice of 8 or 9 weeks were obtained from The University of Edinburgh (UK). After arrival, the animals were weighed and randomly housed in polypropylene cages, stored in rooms with a $12 \mathrm{hr}$ light period, with a temperature and relative humidity of $21 \pm 2^{\circ} \mathrm{C}$ and $50 \pm 5 \%$, respectively. All mice were given free access to tap water and standard mouse chow diet. The animals were kept under specific pathogen free conditions.

Prior to injections, the NMs were dispersed in sterile water with $2 \%$ mouse serum, according to the ENPRA protocol [17]. Mice were randomly assigned into cages in groups of 3 , before being injected via the lateral tail vein, using a 27 gauge needle. All animals were kept under isoflurane anaesthesia, during the injection process (placed on a thermostat controlled heating device at $37^{\circ} \mathrm{C}$ ). Animals were exposed to either a single dose of the different nanomaterials $(128 \mu \mathrm{g} / \mathrm{ml}$ in 100 $\mu \mathrm{l}$ ), or three doses of $100 \mu \mathrm{l}$ of $64 \mu \mathrm{g} / \mathrm{ml}$, every $24 \mathrm{hr}$. A positive control of Lipopolysaccharide (LPS) $(50 \mu \mathrm{l}$ of $100 \mu \mathrm{g} / \mathrm{ml})$ was also employed. The mice were dissected $6,24,48$ and $72 \mathrm{hr}$ after the single IV injection or $72 \mathrm{hr}$, after the triple injection regime (anaesthetised before being killed by cervical dislocation). The liver was then divided into four pieces. The middle lobe was divided into two-one half (about $0.2 \mathrm{~g}$ of tissue) was stored in RNAlater (Life Technologies, UK). The left lobe was removed for MPO analysis (about $0.3 \mathrm{~g}$ of tissue). The right lobe was preserved in $10 \%$ formaldehyde for immunohistochemistry (about $0.3 \mathrm{~g}$ of tissue).

A mouse MPO ELISA kit (Hycult Biotech, USA) was utilised to quantify neutrophil influx into the liver tissue. Briefly, the tissue was lysed in a buffer consisting of $5 \mathrm{mM}$ EDTA, $10 \mathrm{mM}$ Tris, $10 \%$ glycerine, $1 \mathrm{mM}$ phenylmethylsulfonyl fluoride, $1 \mu \mathrm{g} / \mathrm{ml}$ leupeptin and $28 \mu \mathrm{g} / \mathrm{ml}$ aprotinin ( $\mathrm{pH}$ 7.4). The samples were centrifuged twice at $1500 \mathrm{~g}$ for 15 mins at $4^{\circ} \mathrm{C}$ to reduce contamination with cell debris. All samples were diluted 4 fold before being used in the ELISA kit, according to the manufacturer's instructions.

The fixed tissue sections were transferred to embedding cassettes, before being dehydrated in $70 \%$ ethanol ( 2 changes, $1 \mathrm{hr}$ each), $80 \%$ ethanol ( 2 changes, $1 \mathrm{hr}$ each), 95\% ethanol ( 2 changes, $1 \mathrm{hr}$ each), $100 \%$ ethanol ( 3 changes, $1 \mathrm{hr}$ each) and Histoclear II ( 3 changes, 1 $\mathrm{hr}$ each). The tissues were then embedded in paraffin wax $\left(56-58^{\circ} \mathrm{C}\right.$ 2 changes, $1.5 \mathrm{hr}$ each). The blocks were cut into thin slices $(4 \mu \mathrm{m})$, before being transferred to a $45^{\circ} \mathrm{C}$ water bath. The paraffin sections were moved onto polysine glass slides, brushed into position, before being dried overnight at $37^{\circ} \mathrm{C}$. The slides were rehydrated in Histoclear II ( 2 changes, 3 mins), Histoclear II 1:1 with $100 \%$ ethanol ( 3 mins), $100 \%$ ethanol ( 2 changes, 3 mins), $95 \%$ ethanol ( 3 mins), $70 \%$ ethanol ( 3 mins), and $50 \%$ ethanol ( 3 mins). The sections were then washed in Tris Buffered Saline (TBS) plus $0.025 \%$ Triton X-100 ( $2 \times 5$ mins), and blocked $10 \%$ FCS in TBS for $2 \mathrm{hr}$ at room temperature. The primary antibody diluted in TBS with 1\% BSA (rat anti-mouse Ly-6B.2 alloantigen-AbD Serotec, UK) was applied (100 $\mu$ l per slide). The slides were incubated overnight at $4^{\circ} \mathrm{C}$.

The slides were rinsed $2 \times 5$ mins in TBS plus $0.025 \%$ triton, and incubated in $0.3 \% \mathrm{H}_{2} \mathrm{O}_{2}$ in TBS for 15 mins. The HRP conjugated secondary antibody was applied (human anti rat IgG2b: HRP-AbD Serotec, UK), before incubation at room temperature for $1 \mathrm{hr}$. The slides were rinsed $3 \times 5$ TBS and developed with $100 \mu$ lof DAB substrate kit (abcam, USA). The slides were washed and mounted with Mowiol 4-88 (Polysciences Inc., UK).

Liver samples were homogenised in liquid nitrogen, using a mortar and pestle. Homogenised tissues were stored at $-80^{\circ} \mathrm{C}$, before RNA was

\begin{tabular}{|l|l|l|l|}
\hline NM code & NM type & Average size (suppliers information) & Size in water with 2\% serum (DLS) $\boldsymbol{\Psi}$ \\
\hline NM 110 & $\mathrm{ZnO}$ & $100 \mathrm{~nm}$ & $142.7 \mathrm{~nm}$ \\
\hline NM 111 & $\mathrm{ZnO}$ & $130 \mathrm{~nm}$ & $165.31 \mathrm{~nm}$ \\
\hline NM 300 & $\mathrm{Ag}$ & $<20 \mathrm{~nm}$ & $42.94 \mathrm{~nm}$ \\
\hline NM 400 & MWCNT & $30 \mathrm{~nm} 5 \mu \mathrm{m}$ long & NA \\
\hline NM 402 & MWCNT & $30 \mathrm{~nm} 5 \mu \mathrm{m}$ long & NA \\
\hline NRCWE 002 & $\mathrm{TiO}_{2}$ & $10 \mathrm{~nm}$ & $116.54 \mathrm{~nm}$ \\
\hline
\end{tabular}

$\Psi$ Intensity based size average in biological media after 15 mins

Table 1: Average size of tested NMs as supplied by suppliers and as measured by DLS. 
Citation: Kermanizadeh A, Brown DM, Hutchison GR, Stone V (2013) Engineered Nanomaterial Impact in the Liver following Exposure via an Intravenous Route-The Role of Polymorphonuclear Leukocytes and Gene Expression in the Organ. J Nanomed Nanotechol 4: 157. doi:10.4172/2157-7439.1000157

extracted and isolated using the MagMAX ${ }^{\mathrm{TM}}-96$ Total RNA Isolation Kit (Ambion, USA). RNA concentration and purity were measured on a Nanodrop 2000c system (Thermo Scientific, UK). The High Capacity cDNA RT kit (Applied Biosystems, UK) was used according to the protocol, to transcribe RNA into cDNA. Equal quantities of RNA from 3 animals in the same treatment group were pooled and $300 \mathrm{ng}$ of RNA were used in RT reactions. PCRs were conducted in triplicate on a 7900 RT fast PCR system and SDS 2.3 software in 384 well plates (Applied Biosystems, USA), using TaqMan kits, with FAM dye under standard TaqMan conditions for 50 cycles. The following Applied Biosystems kits were used: Mouse kits Mm00437762-m1-B2m (housekeeping gene); Mm00436450-m1-CXCL2; Mm00439614-m1-IL10; Mm00443258-31-TNF- $\alpha$; Mm00437858-m1-C3; Mm00438864-m1Fas ligand; Mm00516023-m1-ICAM-1; Mm00802090-m1-albumin and Mm00446190-m1-IL6.

All data are expressed as mean \pm standard error of the mean. For statistical analysis, the experimental results were compared to their corresponding control values, using an ANOVA with Tukey's multiple comparison. All statistical analysis was carried out utilizing Minitab 15. A $p$ value of $<0.05$ was considered to be significant. All experiments were repeated a minimum of three times.

\section{Results and Discussion}

This study was conducted as part of a large consortium (FP7 funded project-ENPRA), to investigate the potential hazard of a wide range of nanomaterials on a variety of targets, in order to use the data for generation of a structure activity relationship and for modelling risk assessment. Several studies have demonstrated that NMs entering the body via the lungs, ingestion or direct injection accumulate in the liver [7-9]. In previous studies, it has been shown that hepatocytes are capable of producing potent neutrophil chemoattractants (humanIL8 $[15,16,18,19]$ rat-CINC-3) [20], following exposure to foreign matetrials, or in disease models. We therefore investigated neutrophil infiltration into the liver, following IV exposure of mice to a panel of engineered nanomaterials. Our previous studies have demonstrated that the panel of engineered nanomaterials investigated could be divided into a relatively high toxicity group and a lower toxicity group, according to their ability to induce cytotoxicity in the C3A cell line [16], primary human hepatocytes [19], primary rat co-cultures of hepatocytes and kupffer cells. Hence, six nanomaterials were chosenthree of which were shown to be of higher toxicity (Ag and two $\mathrm{ZnO}$ $\mathrm{NMs}$ ), and three that were of relatively low toxicity (positively charged $\mathrm{TiO}_{2}$ and two MWCNTs), in the in vitro systems.

Myeloperoxidase is a lysosomal protein stored in granules of all granulocytes, and is found in largest quantities in neutrophils. In order to quantify PMN infiltration into the liver, we measured this enzyme in tissue samples. A modest but statistically significant increase in MPO in the liver, as early as $6 \mathrm{hr}$, following intravenous injection of the NMs was detected (Figure 1) $(\mathrm{p}<0.05)$. MPO content of the liver tissue had decreased to control levels by $48 \mathrm{hr}$, following exposure to $\mathrm{Ag}$ and $\mathrm{TiO}_{2}$ (Figure 2). Multiple doses of $\mathrm{Ag}$ and $\mathrm{TiO}_{2} \mathrm{NMs}$ did not enhance the MPO up-regulation further (Figure 3).

To confirm the increase in MPO in liver homogenates (Figure 1-3), and whether or not this was associated with the neutrophil influx, liver sections from exposed animals were stained using a specific neutrophil cell surface marker (Ly-6B.2). Staining demonstrated the presence of neutrophils in the tissues exposed to the positive control and the panel of nanomaterials, $6 \mathrm{hr}$ post exposure, which were not evident in the negative control (Figure 4). Furthermore, the relative numbers

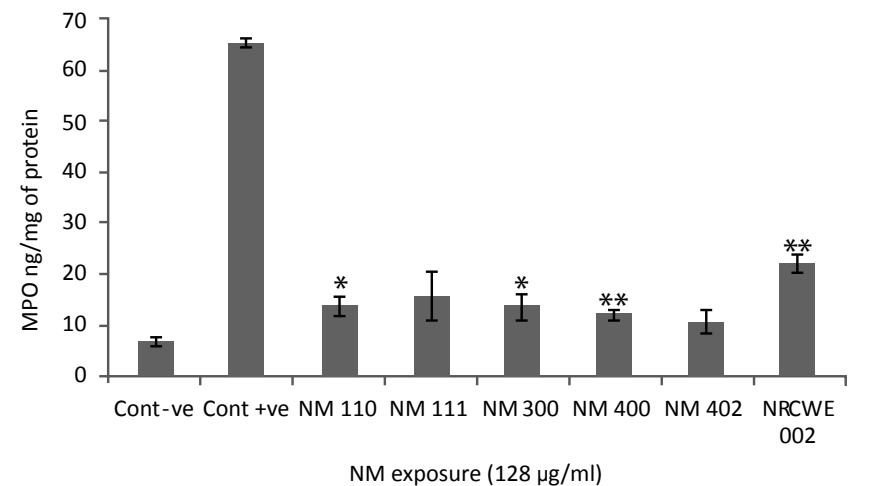

Figure 1: MPO measured in the liver tissue following $6 \mathrm{hr}$ exposure to $100 \mu \mathrm{l}$ in $128 \mu \mathrm{g} / \mathrm{ml}$ of the panel of NMs (NM 110-ZnO uncoated; NM 111-ZnO coated NM 300-Ag; NM 400-MWCNT; NM 402-MWCNT; NRCWE 002-positively charged $\mathrm{TiO}_{2}$. A positive control of LPS ( $50 \mu \mathrm{l}-100 \mu \mathrm{g} / \mathrm{ml}$ ) was also employed. The negative control is representative of animals injected with $100 \mu \mathrm{l}$ of PBS. $\left(n=3 \pm\right.$ SEM) ${ }^{*} P<0.05,{ }^{* *} P<0.005$ compared to negative control.

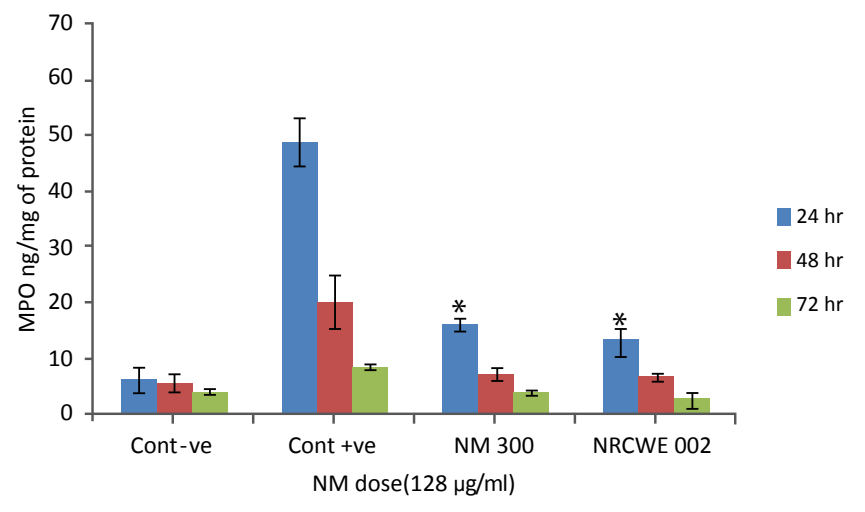

Figure 2: MPO measured in the liver following 24,48 and $72 \mathrm{hr}$ exposure to $100 \mu \mathrm{l}$ of $128 \mu \mathrm{g} / \mathrm{ml}$ the NM 300-Ag and NRCWE 002-positively charged $\mathrm{TiO}_{2}$. A positive control of LPS $(50 \mu \mathrm{l}-100 \mu \mathrm{g} / \mathrm{ml})$ was also employed. The negative control is representative of animals injected with $100 \mu \mathrm{l}$ of PBS. $(n=3 \pm$ SEM) ${ }^{*} \mathrm{P}<0.05,{ }^{* *} \mathrm{P}<0.005$ compared to negative control.

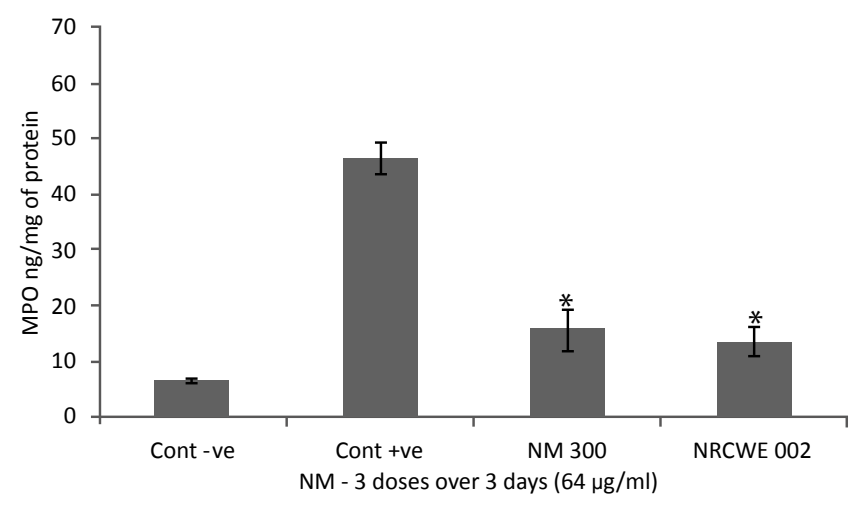

Figure 3: MPO measured in the liver following 3 repeated doses of NMs ove three days ( 3 doses of $100 \mu \mathrm{l}$ of $64 \mu \mathrm{g} / \mathrm{ml}$ every $24 \mathrm{hr}$ ). The animals were dissected $72 \mathrm{hr}$ following the initial dose. The negative control is representative of animals injected with three doses of $100 \mu \mathrm{l}$ of PBS, while the positive contro animals were injected with three doses of LPS $(50 \mu \mathrm{l}-50 \mu \mathrm{g} / \mathrm{ml}$ per injection) $(n=3 \pm S E M){ }^{*} P<0.05,{ }^{* *} P<0.005$ compared to negative control. 
Citation: Kermanizadeh A, Brown DM, Hutchison GR, Stone V (2013) Engineered Nanomaterial Impact in the Liver following Exposure via an Intravenous Route-The Role of Polymorphonuclear Leukocytes and Gene Expression in the Organ. J Nanomed Nanotechol 4: 157. doi:10.4172/2157-7439.1000157

of neutrophils stained in the tissues were comparable to the levels of MPO in liver in the time course experiments, showing that there was a decrease in neutrophil staining $\left(\mathrm{Ag}\right.$ and $\left.\mathrm{TiO}_{2}\right)$ (Figure 5). Multiple dose of the silver and $\mathrm{TiO}_{2}$ also reflected the MPO results, showing that repeated exposures did not further enhance the neutrophil influx into the tissue (Figure 6).

Very low doses $(12.8 \mu \mathrm{g}$ of NMs per animal for single exposure or $19.2 \mu \mathrm{g}$ per animal for repeated exposure experiments) of NMs were injected into the mice in this study to represent a realistic exposure and to avoid toxicity to the animal. These doses are not dissimilar to other studies in which animals have been exposed to NMs via an IV route $[21,22]$. The findings in this study suggest that neutrophils are involved in the organs immunity to the foreign nanomaterials. To our knowledge, the role of neutrophils in the liver, following nanomaterial exposure has not been addressed previously, however, it has been shown that nautrophils can accumulate within hepatic microvasculature, following increase in inflammatory mediators such
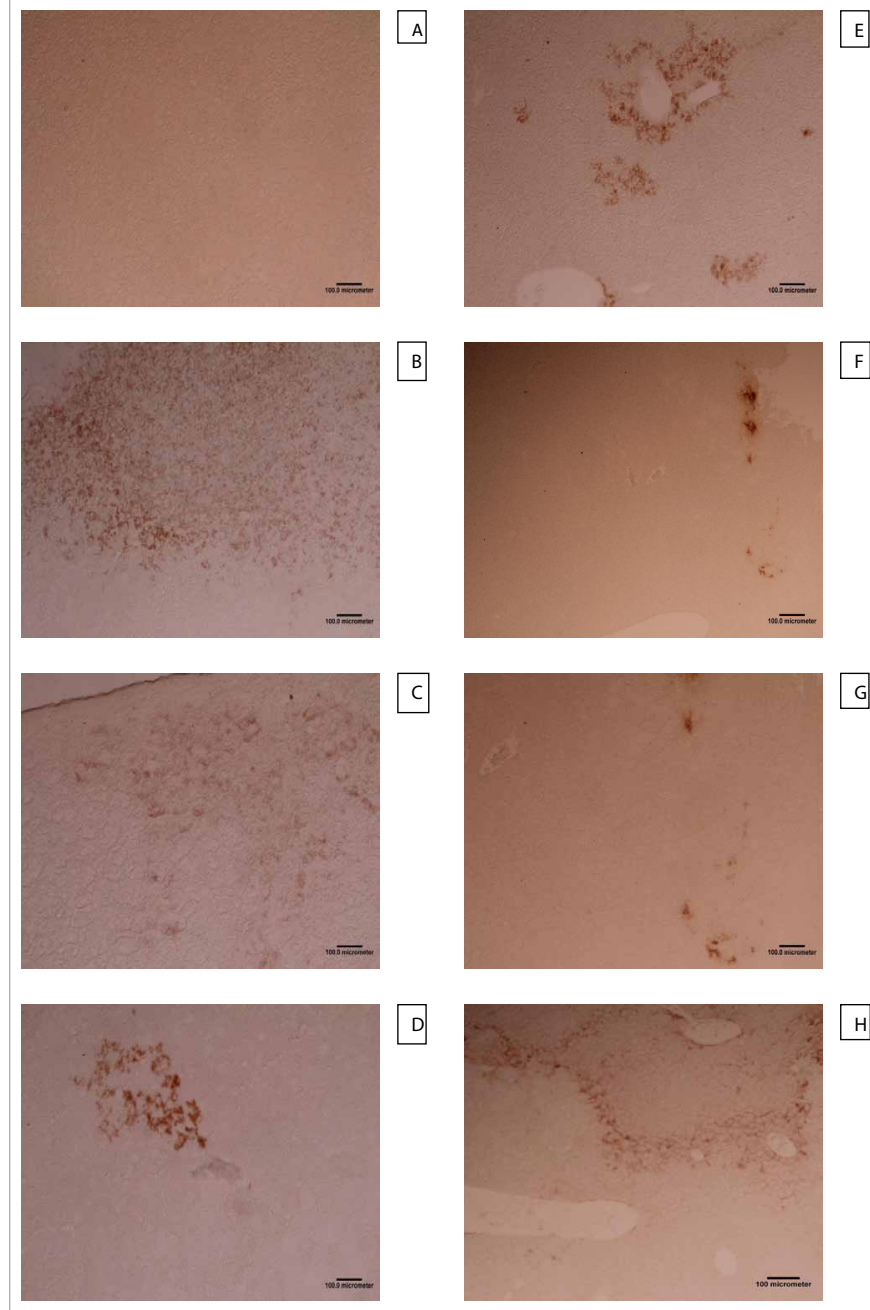

Figure 4: Ly6B.2 staining of mouse liver tissue by immunohistochemistry, 6 hr post intravenous exposure to ENPRA panel of engineered nanomaterials $(100 \mu \mathrm{l}-128 \mu \mathrm{g} / \mathrm{ml}$ of NMs). A positive control of LPS $(50 \mu \mathrm{l}-100 \mu \mathrm{g} / \mathrm{ml})$ was also employed. The negative control is representative of animals injected with $100 \mu \mathrm{l}$ of PBS.

\section{A) PBS B) LPS C) NM 110 D) NM 111 E) NM 300 F) NM 400 G) NM 402 H)} NRCWE 002
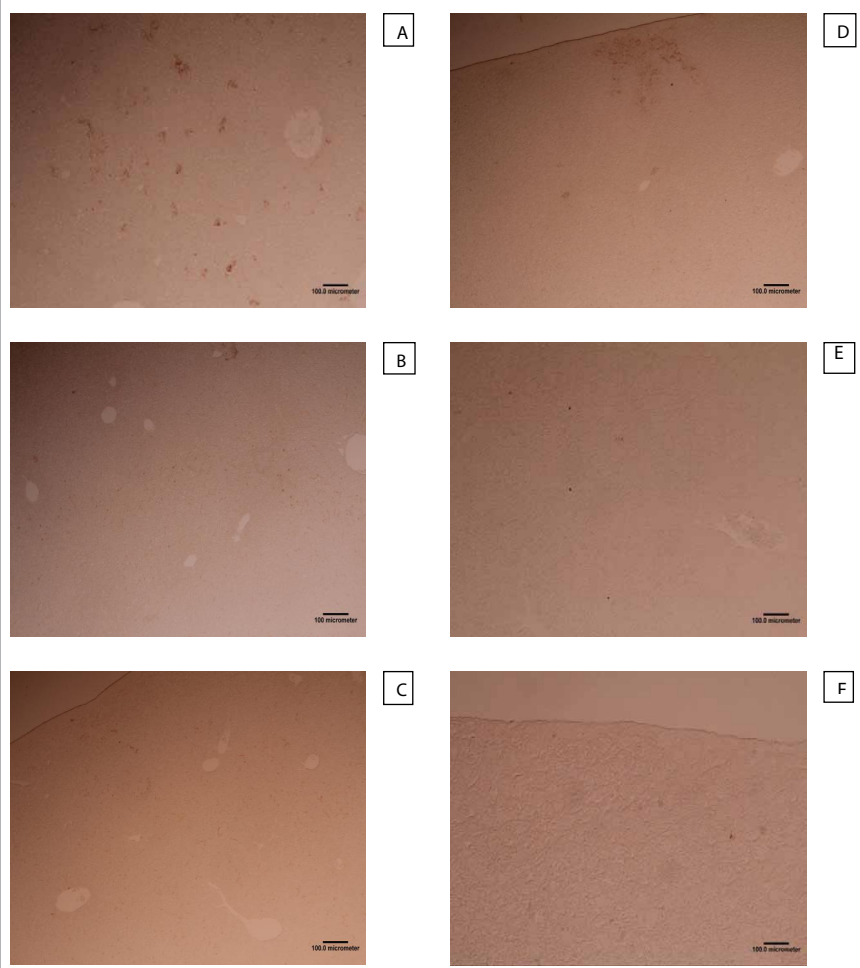

Figure 5: Ly6B.2 staining of mouse liver tissue by immunohistochemistry representing samples from animals 24,48 or $72 \mathrm{hr}$ post intravenous exposure to ENPRA panel of engineered nanomaterials (100 $\mu \mathrm{l}-128 \mu \mathrm{g} / \mathrm{ml}$ of NMs).

A) NM 300-24 hr B) NRCWE 002-24 hr C) NM 300-48 hr D) NRCWE 002$48 \mathrm{hr}$ E) NM 300-72 hr F) NRCWE 002-72 hr.
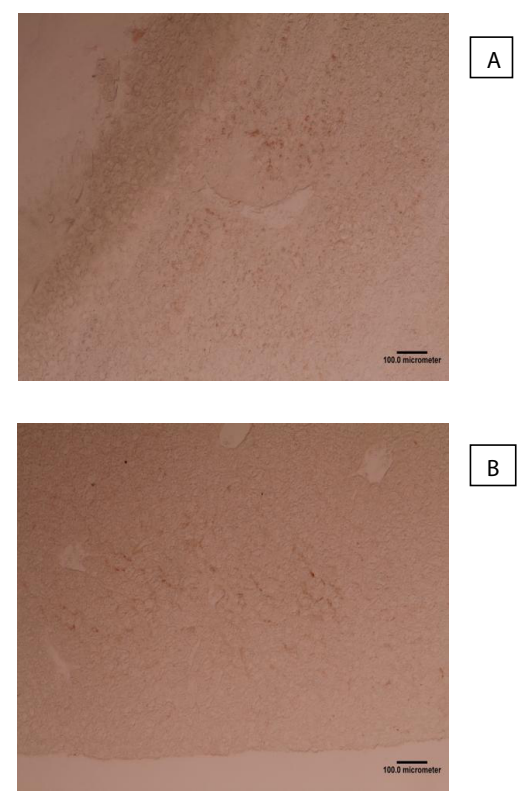

Figure 6: Ly6B.2 staining of mouse liver tissue by immunohistochemistry following three repeated doses over three days (3 doses of $100 \mu \mathrm{l}$ of $64 \mu \mathrm{g} /$ $\mathrm{ml}$ of NMs every $24 \mathrm{hr}$ ). The animals were dissected $72 \mathrm{hr}$, following the initial dose.

A) NM 300 B) NRCWE 002. 
Citation: Kermanizadeh A, Brown DM, Hutchison GR, Stone V (2013) Engineered Nanomaterial Impact in the Liver following Exposure via an Intravenous Route-The Role of Polymorphonuclear Leukocytes and Gene Expression in the Organ. J Nanomed Nanotechol 4: 157. doi:10.4172/2157-7439.1000157

Page 5 of 7

as TNF- $\alpha$, IL1, MIP-2 and PAF $[23,24]$. Furthermore, in a recent study, an increase in numbers of neutrophils in the liver of $\mathrm{BALB} / \mathrm{c}$ mice was observed during anaphylaxis [25].

In this study, it appears that the neutrophils are involved predominately in the initial phases of the immune response, on exposure to the NMs. The initial increase in neutrophil numbers in liver tissue was resolved by $48 \mathrm{hr}$ post exposure. Neutrophils in other organs i.e. the lung are important part of the early innate immune response, as early as $4 \mathrm{hr}$ post exposure to different antigen challenges $[26,27]$, and can be involved in long term inflammation [28]. After the initial infiltration of the neutrophils into the tissue, the resident macrophages (Kupffer cells) may take over the immune response to the nanomaterials. It was also very interesting to note that repeated doses of the nanomaterials did not result in further accumulation of the polymorphonuclear leukocytes into the tissue, confirming our previous suggestion that neutrophils play no further part in the maintenance or the continuation of the inflammatory response.

It has been shown that the most common neutrophil mediated response in the liver is governed by the adhesion of the cells to hepatocytes (via ICAM-1 binding Mac-1) [24,29]. This adhesion triggers the formation of Reactive Oxygen Species (ROS) by NADPH oxidase, and release of proteases through the degranulation of the PMNs. This process could lead to neutrophilic hepatitis, characterised by self aggravating mechanisms, resulting in chronic disease [29]. This prolonged neutrophils response does not happen, following exposure to the nanomaterials utilised in this study. As already mentioned, the neutrophils decrease in number with time after the initial exposure. In addition, the up-regulation of ICAM-1 mRNA was only noted after 24 $\mathrm{hr}$ and had returned to normal levels $48 \mathrm{hr}$ post IV NM exposure.

The expression of a range of genes related to inflammation, oxidative stress and apoptosis was analysed in the livers of mice exposed to the panel of engineered nanomaterials. Analysis of mRNA expression in mouse liver $6 \mathrm{hr}$ after intravenous injection of $100 \mu \mathrm{l}$ of $128 \mu \mathrm{g} / \mathrm{ml}$ of the panel of nanomaterials showed a decrease in C3 following exposure to $\mathrm{ZnO}$ (NM 110 and NM 111), MWCNT (NM 400 and NM 402) (Table 2). We noted a decrease in IL6 mRNA levels, following exposure to $\mathrm{ZnO}$ (NM 110, NM 111) and Ag NMs (NM 300) (Table 1). An increase in IL10 was observed, following exposure to $\mathrm{ZnO}$ (NM 110) and $\mathrm{TiO}_{2}$ (NRCWE 002) (Table 1). Finally, a large increase in CXCL2 was demonstrated, following exposure to $\mathrm{ZnO}$. No significant changes were detected in the expression of albumin, TNF- $\alpha$, albumin, Fas ligand or ICAM-1, following treatment with any of the nanomaterials (Table 2).

Repeated exposure of the C57/BL6 mice to three doses of the Ag (NM 300) and positively charged $\mathrm{TiO}_{2}$ (NRCWE 002) nanomaterials resulted in a large increase in IL10 levels, while smaller yet significant decreases in C3 and ICAM-1 mRNA were noted, following exposure to both $\mathrm{NMs}\left(\mathrm{Ag}\right.$ and $\mathrm{TiO}_{2}$ ) (Table 3).

Finally, the animals were exposed to a single dose of $100 \mu \mathrm{l}$ of 64 $\mu \mathrm{g} / \mathrm{ml}$ of the $\mathrm{Ag}$ and positively charged $\mathrm{TiO}_{2} \mathrm{NMs}$ by injection via the lateral tail vein. The animals were dissected $24 \mathrm{hr}, 48 \mathrm{hr}$ and $72 \mathrm{hr}$ after the initial injection. We found that in all instances, the increase or decrease in mRNA was most evident after the $24 \mathrm{hr}$ exposure. For all the genes investigated in this study, resolution to control levels had occurred $72 \mathrm{hr}$ post exposure (Tables 4 and 5).

Complement factor 3 is one of the most abundant and important proteins in the complement cascade. C3 activation is essential for all the functions of the complement system. It is crucial in promoting phagocytosis, supporting the local immune response against foreign agents, and instructing the adaptive immune responses to select the appropriate antigens for any eventual antibody response [30]. Moreover, C3 might be capable of interaction with the coagulation system and contributing to pro-coagulation, and ultimately, a prothrombotic state [31]. The decrease in C3 expression might suggest that exposure to low doses of NMs in this study results in overall tolerance in the liver, rather than a fully developed immune response.

There was a decrease in IL6 mRNA levels, following exposure to the $\mathrm{ZnO}$ and $\mathrm{Ag} \mathrm{NMs}$, after $6 \mathrm{hr}$ exposure. IL6 is a multifunctional cytokine that acts on a number of cell types, including B and T lymphocytes, hepatocytes, hematopoietic progenitor cells and neuronal cells [32]. Under different circumstances, the cytokine can be both pro- and anti-inflammatory. In the liver, IL6 is a potent inducer of acute phase proteins, which are in most part pro-inflammatory proteins (including $\mathrm{C}$ reactive protein, complement factors and serum amyloid A) [33]. Once again, the decrease in IL6 expression advocates that exposure to low doses of these NMs results in tolerance in the liver.

IL10 is a multifunctional cytokine with diverse effects on a wide range of hemopoietic cells. The cytokine's principle function is to terminate inflammatory responses [34]. IL10 also regulates growth or differentiation of B and T lymphocytes, NK cells, mast cells, most granulocytes, dendritic cells, keratinocytes, and endothelial cells [35]. IL10 also plays a key role in differentiation of regulatory T cells, which figure prominently and importantly in the control of immune responses, and developing a tolerant immune state [35]. Analysis of IL10 mRNA showed an increase, following exposure to exposure to

\begin{tabular}{|l|l|l|l|l|l|l|}
\hline $\begin{array}{l}\text { Gene } \\
\text { Expression }\end{array}$ & NM 110 & NM 111 & NM 300 & NM $\mathbf{4 0 0}$ & NM 402 & NRCWE 002 \\
\hline IL6 & $-200 \%$ & $-50 \%$ & $-200 \%$ & 0 & 0 & 0 \\
\hline IL10 & $+75 \%$ & 0 & 0 & 0 & $+50 \%$ & $+200 \%$ \\
\hline C3 & $-50 \%$ & $-75 \%$ & $-75 \%$ & $-50 \%$ & $-75 \%$ & 0 \\
\hline CXCL2 & $+200 \%$ & 0 & 0 & 0 & 0 & 0 \\
\hline TNF-a & 0 & 0 & 0 & 0 & 0 & 0 \\
\hline Fas ligand & 0 & 0 & 0 & 0 & 0 & 0 \\
\hline ICAM-1 & 0 & 0 & 0 & 0 & 0 & 0 \\
\hline Albumin & 0 & 0 & 0 & 0 & 0 & 0 \\
\hline
\end{tabular}

Table 2: mRNA expression of inflammatory cytokines and receptors, FasL and albumin in C57/BL6 mice liver. The animals were exposed to $100 \mu \mathrm{l}$ of $128 \mu \mathrm{g}$ $\mathrm{ml}$ of panel of nanomaterials for $6 \mathrm{hr}$ by injection via the lateral tail vein. mRNA expression was analysed by real time PCR with B2m utilised as an endogenous control.

\begin{tabular}{|l|l|l|}
\hline Gene Expression & NM $\mathbf{3 0 0}$ & NRCWE 002 \\
\hline IL6 & 0 & 0 \\
\hline IL10 & $+200 \%$ & $+200 \%$ \\
\hline C3 & $-100 \%$ & $-100 \%$ \\
\hline CXCL2 & 0 & 0 \\
\hline TNF- $\alpha$ & $+50 \%$ & 0 \\
\hline Fas Ligand & 0 & 0 \\
\hline ICAM-1 & $-100 \%$ & $-100 \%$ \\
\hline Albumin & 0 & 0 \\
\hline
\end{tabular}

Table 3: mRNA expression of inflammatory cytokines and receptors, FasL and albumin in C57/BL6 mice liver. The animals were exposed three times $(0 \mathrm{hr}, 24 \mathrm{hr}$ and $48 \mathrm{hr}$ ) to $100 \mu \mathrm{l}$ of $64 \mu \mathrm{g} / \mathrm{ml}$ of the $\mathrm{Ag}(\mathrm{NM} \mathrm{300})$ and the positively charged $\mathrm{TiO}_{2}$ NMs by injection via the lateral tail vein. The animals were dissected $72 \mathrm{hr}$ after the first injection and the mRNA expression was analysed by real time PCR, with B2m utilised as an endogenous control. 
Citation: Kermanizadeh A, Brown DM, Hutchison GR, Stone V (2013) Engineered Nanomaterial Impact in the Liver following Exposure via an Intravenous Route-The Role of Polymorphonuclear Leukocytes and Gene Expression in the Organ. J Nanomed Nanotechol 4: 157. doi:10.4172/2157-7439.1000157

Page 6 of 7

\begin{tabular}{|l|l|l|l|}
\hline Gene Expression (NM 300) & Day 1 & Day 2 & Day 3 \\
\hline C3 & $-75 \%$ & $-50 \%$ & 0 \\
\hline IL6 & $+100 \%$ & $+100 \%$ & 0 \\
\hline IL10 & $+200 \%$ & $+75 \%$ & 0 \\
\hline CXCL2 & 0 & 0 & 0 \\
\hline TNF- $\alpha$ & 0 & 0 & 0 \\
\hline Fas Ligand & $+75 \%$ & 0 & 0 \\
\hline ICAM-1 & $+75 \%$ & 0 & 0 \\
\hline Albumin & 0 & 0 & 0 \\
\hline
\end{tabular}

Table 4: mRNA expression of inflammatory cytokines and receptors, FasL and albumin in C57/BL6 mice liver. The animals were exposed to a single dose of $100 \mu \mathrm{l}$ of $128 \mu \mathrm{g} / \mathrm{ml}$ of the Ag NM (NM 300), by injection via the lateral tail vein. The animals were dissected $24 \mathrm{hr}, 48 \mathrm{hr}$ and $72 \mathrm{hr}$ after the initial injection and the mRNA expression was analysed by real time PCR with B2m utilised as an endogenous control.

\begin{tabular}{|l|l|l|l|}
\hline Gene Expression (NRCWE 002) & Day 1 & Day 2 & Day 3 \\
\hline C3 & $-75 \%$ & 0 & 0 \\
\hline IL6 & 0 & 0 & 0 \\
\hline IL10 & $+200 \%$ & $+200 \%$ & 0 \\
\hline CXCL2 & 0 & 0 & 0 \\
\hline TNF- $\alpha$ & 0 & 0 & 0 \\
\hline Fas Ligand & $+75 \%$ & 0 & 0 \\
\hline ICAM-1 & $+75 \%$ & 0 & 0 \\
\hline Albumin & 0 & 0 & 0 \\
\hline
\end{tabular}

Table 5: mRNA expression of inflammatory cytokines and receptors, FasL and albumin in C57/BL6 mice liver. The animals were exposed to a single dose of 100 $\mu \mathrm{l}$ of $128 \mu \mathrm{g} / \mathrm{ml}$ of the $\mathrm{TiO}_{2} \mathrm{NM}$ (NRCWE 002) by injection via the lateral tail vein. The animals were dissected $24 \mathrm{hr}, 48 \mathrm{hr}$ and $72 \mathrm{hr}$ after the initial injection and the mRNA expression was analysed by real time PCR, with B2m utilised as an endogenous control.

NM 110 (uncoated ZnO), NM 300 (Ag), NM 402 (MWCNT) and NRCWE $002\left(\mathrm{TiO}_{2}\right)$. The increase in IL10 mRNA was the largest and the most significant of all the genes investigated in this study, once again suggesting tolerance as being the overall response in the organ, following acute low exposure to NMs.

CXCL2 also known as Macrophage Inflammatory Protein 2 alpha (MIP-2) is a chemokine secreted from a number of cell types, in particular, monocytes and macrophages [36]. CXCL2 is a potent chemoattractant for neutrophils and hematopoetic stem cells [36]. A large increase in CXCL2 was observed following exposure to NM 110 (uncoated $\mathrm{ZnO}$ ), following $6 \mathrm{hr}$ exposure. It is important to note that increases compared to base levels of CXCL2 were also demonstrated following the $6 \mathrm{hr}$ exposure to other nanomaterials, however, due to large fluctuations in the control group of animals, these changes could not be regarded as significant. Up-regulation of CXCL2 could be associated with the short term acute recruitment of PMNs into the liver.

No significant changes were detected in the expression of albumin, TNF- $a$, Fas ligand or ICAM-1, following $6 \mathrm{hr}$ exposure to any of the nanomaterials utilised in this study. The fact that there was no change in the levels of TNF- $\alpha$ would again suggest that there is no significant pro-inflammatory response, following exposure to the NMs. FasL (also referred to as CD95L) is a homotrimeric type II transmembrane protein signalling through trimerisation with CD95 on the target cells, leading to death by apoptosis [37]. The findings here would suggest that there is no apoptosis, following exposure to these particular nanomaterials at the time points used here, however, it is possible that FasL may be upregulated at later time points, in relation to the clearance of PMN from the liver. There was no change in albumin gene expression suggesting that the NM challenge at these low doses does not affect liver function.

Repeated exposure of the mice to three doses of the Ag (NM 300) and positively charged (NRCWE 002) nanomaterials again resulted in large increases in IL10 levels, while smaller yet significant decreases in C3 and ICAM-1 mRNA were noted, following exposure to both NMs. ICAM-1 (Intracellular Adhesion Molecule 1) is a molecule involved in attraction and adhesion of inflammatory cells to endothelial and epithelial cells, and its soluble form, sICAM-1, is linked to activation of these cells in pathological responses [38]. It is up-regulated in liver associated diseases, such as in hepatitis C [38]. As already mentioned, binding of ICAM-1 to Mac-1 on hepatocytes is crucial to neutrophil mediated response in the liver. The overall decrease in ICAM-1 mRNA suggests that neutrophils are not involved at the latter stages of the liver immunity, despite fresh foreign nanomaterial challenges.

Finally, a group of animals were exposed to a single dose of $100 \mu \mathrm{l}$ of $64 \mu \mathrm{g} / \mathrm{ml}$ of the $\mathrm{Ag}$ and positively charged $\mathrm{TiO}_{2} \mathrm{NMs}$. The animals were dissected $24 \mathrm{hr}, 48 \mathrm{hr}$ and $72 \mathrm{hr}$ after the initial injection. We found that in all instances, the greatest changes in mRNA occurred after the $24 \mathrm{hr}$ exposure. These changes resolved and all the genes investigated returned to background levels, after $72 \mathrm{hr}$ post exposure.

It is important to emphasize the limitations of this study. It may be important to examine earlier time points to gain a better understanding of the role of neutrophils in the liver, following a NM challenge. Future studies may include the utilisation of microarray analysis for a more comprehensive gene expression profile in the liver. Any potential changes in a large number of genes, including those of the cytochrome $\mathrm{P}_{450}$ family, heat shock proteins and IL1 family of proteins could be important indicators of NM impact on the liver. Furthermore, it might be important to examine presence of neutrophils in blood and compare with liver tissue. It is possible that these cells are also responsible for initiating the reparative process that is later managed by macrophages.

Overall, the findings in this study suggest that intravenous exposure of mice to the ENPRA panel of engineered nanomaterials results in neutrophil governed acute effects in the liver. The low doses used were not sufficient to cause any longer term inflammation in the liver tissue. Any changes that were observed after $24 \mathrm{hr}$ post exposure, in terms of leukocyte infiltration and changes in gene expression related to inflammation, oxidative stress and apoptosis had resolved $72 \mathrm{hr}$ post exposure.

\section{Acknowledgements}

This work has been financially supported by the European seventh framework programme co-operation (Grant code-NMP4-SL-2009-228789). The authors are grateful to colleagues at Heriot-Watt University and Edinburgh Napier University, in particular, Dr Lesley Young.

\section{References}

1. Maynard AD, Aitkin RJ, Butz T, Colvin V, Donaldson K, et al. (2004) Safe handling of nanotechnology. Nature 444: 267-269.

2. Oberdorster G, Oberdorster E, Oberdorster J (2005) Nanotoxicology: an emerging discipline evolving from studies of ultrafine particles. Environ Health Perspect 113: 823-839.

3. http://www.nanotechproject.org/inventories/consumer/browse/products/

4. Ken D, Vicki S (2003) Current hypothesis on mechanisms of toxicity of ultrafine particles. Annali dell'Istituto Superiore di Sanità 39: 405-410.

5. Nel A, Xia T, Madler L, Li N (2006) Toxic potential of materials at the nanolevel. Science 311: 622-627.

6. Papp T, Schiffmann D, Weiss D, Castronova V, Vallyathan V, et al. (2008) Human health implications of nonmaterial exposure. Nanotoxicology 2: 9-27.

7. Chen C, Zhang P, Hou X, Chai Z (1999) Sub-cellular distribution of selenium and Se-containing proteins in human liver. Biochim Biophys Acta 1427: 205215 
Citation: Kermanizadeh A, Brown DM, Hutchison GR, Stone V (2013) Engineered Nanomaterial Impact in the Liver following Exposure via an Intravenous Route-The Role of Polymorphonuclear Leukocytes and Gene Expression in the Organ. J Nanomed Nanotechol 4: 157. doi:10.4172/2157-7439.1000157

8. Diesen DL, Kuo PC (2010) Nitric Oxide and redox regulation in the liver: Part I. General considerations and redox Biology in Hepatitis. J Surg Res 162: 95-109.

9. Sadauskas E, Jacobson NR, Danscher G, Soltenberg M, Larsen A, et al. (2009) Bio-disruption of gold nanoparticles in mouse lung following intratracheal instillation. Chemistry Central Journal 3: 16-23.

10. Semmler-Behnke M, Kreyling WG, Lipka J, Fertsch S, Wenk A, et al. (2008) Bio-distribution of 1.4 and 18-nm gold particles in rats. Small 12: 2108-2111.

11. Kmiec Z (2001) Cooperation of liver cells in health and disease. Adv Anat Embryol Cell Biol 161: 109-113.

12. Freitas M, Lima JLFC, Fernandes E (2009) Optical probes for detection and quantification of neutrophils' oxidative burst. A review. Anal Chim Acta 649: 8-23.

13. Quinn MT, Gauss KA (2004) Structure and regulation of neutrophil respiratory burst oxidase: Comparison with nonphagocyte oxidases. J Leukoc Biol 76 760-781.

14. Nauseef WM (2007) How human neutrophils kill and degrade microbes: an integrated view. Immunol Rev 219: 88-102.

15. Delpino MV, Barrionuevo P, Scian R, Fossati CA, Balsi PC (2010) Brucellainfected heaptocytes mediate potentially tissue-damaging immune responses. Journal of Hepatology 53: 145-54

16. Kermanizadeh A, Pojana G, Gaiser BK, Birkedal R, Bilaničová D, et al. (2012) In vitro assessment of engineered nanomaterials using C3A cells: Cytotoxicity, pro-inflammatory cytokines and function markers. Nanotoxicology.

17. Jacobsen NR, Pojano G, Wallin, H, Jensen KA (2012) Nanomaterial dispersion protocol for toxicological studies in ENPRA. Internal ENPRA Project Report. The National Research Centre for the Working Environment.

18. Kermanizadeh A, Gaiser BK, Hutchison GR, Stone V (2012) An in vitro liver model-assessing oxidative stress and genotoxicity following exposure of hepatocytes to a panel of engineered nanoparticles. Particle and Fibre Toxicology.

19. Kermanizadeh A, Gaiser BK, Ward MB, Stone V (2012) Primary human hepatocytes vs. hepatic cell line-assessing their suitability for in vitro nanotoxicology. Nanotoxicology.

20. Ding Y, Zhao L, Mei H, Zhang SL, Huang ZH, et al. (2008) Exploration of Emodin to treat alpha-naphthylisothiocyanate-induced cholestatic hepatitis via anti-inflammatory pathway. Eur J Pharmacol 590: 377-386.

21. Ivanov S, Zhuravsky S, Yukina G, Tomson V, Korolov D, et al. (2012) In vivo toxicity of intravenously administered silica and silicon nanoparticles. Materials 5: 1873-1889.

22. Tan YK, Best SL, Donnelly C, Olweny E, Kapur P, et al. (2012) Novel iron oxide microparticles used to render stone fragments paramagnetic: assessment of toxicity in a murine model.

23. Bajt ML, Farhood A, Jaeschke H (2001) Effects of CXC chemokines on neutrophil activation and sequestration in hepatic vasculature. Am J Physio Gastrointest Liver Physiol 281: 1188-1195

24. Ramaiah SK, Jaeschke H (2007) Role of neutrophils in the pathogenesis of acute inflammatory liver injury. Toxicol Pathol 35: 456-766.

25. Krishnamurphy D, StarkI P, Szalai K, Roth-Walter F, Diesner SC, et al. (2012) Monitoring neutrophils and platelets during casein-induced anaphylaxis in an experimental BALB/c mouse model. Clin Exp Allergy 42: 1119-1128.

26. Nishiura $\mathrm{H}$ (2013) The alternative C5a receptor function. Adv Exp Med Bio 734: 111-121.

27. Wigenstam E, Jonasson S, Koch B, Bucht A (2012) Corticosteroid treatment inhibits airway hyper responsiveness and lung injury in a murine model of chemical-induced airway inflammation. Toxicology 301: 66-71.

28. Duffin R, Gilmour PS, Schins RPF, Clouter A, Guy K, et al. (2001) Alminium lactate treatment of DQ12 quartz inhibits its ability to cause inflammation, chemokine expression and nuclear factor-kappa B activation. Toxicol App Pharmacol 176: 10-17.

29. Bautista A (2002) Netrophilic infiltration in alcoholic hepatitis. Alcohol 27: 17-21.

30. Sahu A, Lambris JD (2001) Structure and biology of complent protein C3, a connecting link between the innate and acquired immunity. Immunol Rev 180 $35-48$.

31. Hertle E, van Greevenbroek MMJ, Stehouwer CDA (2012) Complement C3 an emerging risk factor in cardiometabolic disease. Diabetologica 55: 881-884.

32. Kishimoto T, Akira S, Narazaki M, Taga T (1995) Interleukin-6 family of cytokines and gp130. Blood 86: 1243-1254.

33. Poli V, Cortese R (1989) Interleukin 6 induces a liver-specific nuclear protein that binds to the promoter of acute-phase genes. Proc Natl Acad Sci U S A 86 : 8202-8206.

34. Moore KW, Malefyt R, Coffman RL, O'Garra A (2001) Interluekin-10 and the interluekin-10 receptor. Annu Rev Immunol 19: 683-765.

35. Mocellin S, Panelli MC, Wang E, Nagorsen D, Marincola FM (2004) The dua role of IL-10. Trends Immunol 24: 36-43.

36. Zamjahn JB, Quinton LJ, Mack JC, Frevert CW, Nelson S, et al. (2011) Differential flux of macrophage inflammatory protein-2 and cytokine-induced neutrophil chemoattractant from the lung after intrapulmonary delivery. AJPLung Physiol 301: L568-L574

37. McIntyre TM (2012) Bioactive oxidatively truncated phospholipids in inflammation and apoptosis: Formation, targets, and inactivation. Biochim Biophys Acta 1818: 2456-2464.

38. Yang PY, Almofti MR, Lu L, Kang H, Zhang J, et al. (2005) Reduction of atherosclerosis in cholestrol-fed rabbits and decrease of expressions of intracellular adhesion molecule-1 and vascular endothelial growth factor in foam cells by a water-soluble fraction of Polygonum multiflorum. J Pharmacol Sci 99: 294-300. 